\title{
Fujita Tsuguharu's Transformation from a Modernist to a War Painter
}

\author{
Wanshi Ma \\ Department of Art History and Archaeology, Columbia University, New York, NY, USA \\ Email:wsm2384@columbia.edu
}

How to cite this paper: Ma, W.S. (2018) Fujita Tsuguharu's Transformation from a Modernist to a War Painter. Open Journal of Social Sciences, 6, 147-155. https://doi.org/10.4236/jss.2018.63010

Received: January 29, 2018

Accepted: March 16, 2018

Published: March 19, 2018

Copyright (C) 2018 by author and Scientific Research Publishing Inc. This work is licensed under the Creative Commons Attribution International License (CC BY 4.0).

http://creativecommons.org/licenses/by/4.0/

\section{c) (i) Open Access}

\begin{abstract}
The Japanese artist Fujita Tsuguharu's oeuvre contains a transformation of style from an intimate manifestation of personal statement to a delineation full of violence and sacrifice. What remains constant in his painting is a mixture of Japanese and European elements, a hybrid identity of this oriental Japanese artist who had spent seventeen-year of his artistic career in Paris.
\end{abstract}

\section{Keywords}

Western Style of Art, Japanese Painting, Oriental Modernism, War,

Propaganda

\section{Introduction}

There is no question that in the early decades of the twentieth century, Paris attracted artists from all over the world who worked in the Western style of art. Some American and European artists remained in Paris for many years, but the situation for Japanese artists in the years leading up to World War II remained peculiar. In the early decades of the twentieth century, many Japanese artists longed to leave their homeland to seek artistic freedom and fortune in Paris. Yet in Japan, they had been instilled with Confucian traditions, which emphasized the virtues of obedience, restraint and self-discipline [1]. These were not the values most useful in adapting to the rebellious atmosphere of Paris in the 1920s. In addition, due to the distance and expenses involved, most of the aspiring Japanese painters who went to Paris could manage to remain for only a relatively short period of time. There were a few exceptions. For example, Fujita Tsuguharu, one of the most colorful figures of the Roaring Twenties, whose art retains an aura of exotic, oriental modernism, had remained for a much longer time, in what seemed to him an altogether glamorous and perhaps productive environ- 
ment.

Fujita arrived in Paris in 1913 at the age of twenty-seven and became a celebrated member of the École de Paris. Along the way, Fujita escaped from cultural isolation by learning to speak French and cultivating European contacts. This little man with big dark myopic eyes behind tortoiseshell rimmed glasses, a bowl haircut, a mustache, and a colorful wardrobe that he designed and made for himself, developed an eccentric persona that placed much importance on his public appearance [2]. In Fujita's active and multicultural social life, not only did he make an astonishing spectacle out of himself at a party given by Kees van Dongen by dancing in a loincloth and singing Japanese folk songs, but he was also introduced to Picasso by Diego Rivera [3].

\section{A Foreign Artist in Paris}

\subsection{Selecting a Template}

Through Picasso, Fujita discovered Henri Rousseau's work The Poet and His Museand was much impressed by it. Characterized by a similar, naïve aesthetic, Fujita's paintings are combined with a more traditional Japanese delicacy. Fujita experimented with flattened, undulating forms, although his palette was much paler and more restrained than Rousseau's [4]. Inevitably, Fujita's style was a blend of East and West. In the words of historian Bert Winther-Tamaki, "he innovated a means of painting the European nude in a manner that Europeans would find flattering to their narcissistic culture, while also expressive of traits they assumed to be authentic products of the artist's Japanese identity" [5].

Kiki was the model in paintings who brought Fujita acclaim. In 1921, he met Kiki-Montparnasse's ubiquitous social icon-on the terrace of La Rotonde. He was looking for models who reminded him of Ingres's Grande Odalisque, and Kiki's white skin was exactly what he was looking for [2]. There followed a series of monochrome odalisques that are among Fujita's most accomplished nudes. In Reclining Nude with Cat (1921), one of Fujita's perceptive, precisely drawn cats sits beside his naked woman, while in Reclining Nude with Toile de Jouy (1922), Kiki is framed by a densely-decorated French fabric. Hovering an inch or so above the sheets, she appears in majesty, regal and serene, smooth as porcelain [2]. Executed in the same kind of simplicity, serenity, and purity of line, Reclining Nude with Toile de Jouyis comparable to Manet's Olympia of 1863. Manet's work presents a young white prostitute reclining on a bed in an awkward pose, close to that of Kiki. This painting violates the convention of representing the nude, which put woman on display for the pleasure of spectators. The nude, like the prostitute, was an erotic commodity for the aesthetic consumer. However, in Manet's painting, she meets the viewer's eyes with a look of detachment. Her alert posture and confrontational gaze suggest that she is aware of her position in relation to her customers. In a similar expression, Fujita's nude looks directly at viewers with her in different expression, which seems to convey the individual consciousness of a contemporary woman. 
In those days, artists usually brought thickly painted bright colors to their paintings, but Fujita made his name on the near monochromatic white surface that seems to be associated with the East Asian tradition of monochrome ink painting. He employed a special, spectacular white in his paintings, a white that seems to give Kiki flesh of ivory. While not quite human, shades of white render the softness and smoothness of skin. Beginning with the white surface, which imparted a unique sense of translucence and depth, he drew his subjects in sinuous black lines with fine Japanese brushes [1].

His linear definition of figures recalls the tradition of Japanese ukiyo-e woodblock prints. Three Beauties of the Present Day (1793) by Kitigawa Utamaro is a woodblock print in the Edo period. Utamaro portrayed the private life of women in the pleasure court of Tokyo. White spaces emphasize the women's white skin and softness. Their noses and the outline of their faces are expressed in thin and continuous lines that appear to be sharply inscribed. The linear contours define and separate each area of color, as well as describe details, gestures, and movements of figures, which give rise to a mysterious quality in this portrait. Fujita, in a style reminiscent of the ukiyo-e pictorial idiom, drew thin but assertive lines in black ink to emphasize the figures' contours. His elegant lines weep around the naked woman's body with confidence, following the curves of hips and calves, seemingly without a break. The line can also be appreciated in the lady's sinuous fingers, which are accurately defined along the way. In addition, he used white paint to create the sensuous and pale skin of women as they were portrayed in ukiyo-e portraits. These identifications of Fujita's Japanese painting style and technique were combined with the European medium of oil on canvas and the genre of the nude painting. Merging the techniques of Japanese ukiyo-e prints with the Western medium, Fujita mixed the practiced spontaneity of the former with careful layering of the latter.

In the milieu of Paris Fauvism, Fujita's artistic achievement in his nearly monochromatic black and white palette can be best appreciated in the company of more colorful works by his European contemporaries [3]. Critical to Fujita's success in achieving European spectators' admiration was his technique of endowing paintings of erotic female bodies with the Japanese aesthetic sensibility of his painting style. Fujita had sought to diminish the perceived foreign materiality of oil-paint pigments by literally mixing native painting ingredients into the oil paint. The signature style of nude painting that Fujita first achieved in the 1920s is well represented by Reclining Nude of 1931. Working in oil, he experimented with line and texture. In his own words, Fujita claimed "I decided to do just the opposite of what the others did. The trend of those days was to pile on the paints widely and apply colors thickly. I decided to bring life to my work by using paints very sparingly and smoothly. I didn't use much color, mainly black and white. While others used a thick brush, I instead tried to create an oil painting by using a fine writing brush" [1]. Indeed, large swaths of white in Fujita's picture surface conveyed the sensation of skin, with "a warm, burnished sheen 
like eggshell". Fujita rendered precisely the contours of his figure, which is barely separated from the monochrome skin-like bedding and background. The dark lines of his figures almost seem to cut into the picture plane and create a gently pulsating effect with subtle contrasts of washed-out color [5].

\subsection{Between East and West}

Fujita combined Western and traditional Japanese art techniques, introducing Japanese stylistic elements into Western oil-painting. Therefore, the artist's individual identity was constructed by an expression of national identity in the international context of the Paris art world. The strategy he employed can be explained as "self-orientalization," which made him a remarkably successful Japanese artist in Paris [6]. Whereas Japanese artists living and working in Paris at that time were largely criticized for emulating the privileged position of the European male artists by painting European female nudes, Fujita took control of his own image in the European society and cultivating his market in Europe by taking advantage of the roles assigned to him and the distinctiveness of his nationality. In terms of his paintings, with an aim of reaching and exceeding the western standard, Fujita though his depiction of female nudes showed distinctive Japanese artistic qualities in an original style.

Fujita's Self-Portrait of 1921 made a comment on his state of mind during the heyday. He had been immersed in the Paris art world for a few years. He had acquired bangs and a little moustache, on the way of perceiving a Parisian personality. He depicted himself with austerity, sitting straight up against a bare white wall of his studio. Viewers can catch a glimpse of his private life from the wooden table, clock, decorated plate, and his smoking equipment. Concealed behind bangs and glasses, the artist did not reveal his inner self, but he remained distant from the viewers without providing further insight into his ordinary life and experience. Nevertheless, Fujita integrated the realities of everyday experience into his oil painting My Room, Still Life with Alarm Clock (1921), which is a look at his studio. A red-checked cloth, oil lamp, pipe, doll and drinking glass were placed on a table. These objects, modest and ordinary in life, acquire the materiality of Fujita's life narrative. Even though the artist himself is not present in this painting. His presence is documented by his association with his belongings. The viewers are invited to explore the artist's feelings and thoughts. Fujita turned his quotidian experience into an artwork that generates an intimate contact between the viewers and the artists. This painting was exhibited at the 1922 Imperial Salon in Tokyo, as one of the endless efforts Fujita made to gain approval in his native country. Nevertheless, in the eyes of many Japanese, black lines and white spaces were abundantly available in their traditional work on paper and silk. Without any resemblances to Impressionist paintings, Fujita's My Room, Still Life with Alarm Clock was a step backward [1].

In one of his letters to his Japanese wife Tomi, Fujita stated his goal in Pairs, "I will create works that the Westerners can't, something containing the art of the 
East's Japan. Of course the material will be oils, but the results will be impressive valuable as work of art”. French art critic praised him for not ignoring his Japanese heritage or blindly copying the west, however, his Japanese-style oil painting was denounced as opportunistic in Japan [1]. Critics condemned him for alluding to the tradition of ukiyo-e prints and foregrounding his Japanese identity for pandering to Western desires for orientalia. In the eyes of many Japanese, Fujita employed the clever tactics to appeal to the European audience rather than to sincerely appreciate the Japanese aesthetics of old traditions and advance an authentic expression of national identity.

Different perceptions of the artist and his work, both in Japan and France, made Fujita a complex figure. Despite the controversy, Fujita's fame in Paris gained him recognition among the Japanese. He decided to resettle in Japan in 1933, when the Japanese Empire was in a time of significant expansion. He dramatically transformed his public persona and artistic identity in accordance with the progressively reactionary political climate of Japan, from a member of international art community into a promoter of Japan's military and cultural ambitions [1]. In contrast to the time in Paris, when Fujita earned recognition through introducing Japanese elements to Western oil paintings, now he began to seek a new position in Japan as a cultural ambassador bridging the gap between Japan and Western countries. Along the way, he declared both his international success and his patriotic spirit.

\section{Reemergence as a War Painter}

\subsection{In the Midst of the War}

Beginning with the Manchurian Incident in 1931, escalating with the Marco Polo Bridge Incident in 1937 to the full-scale war with China, and then expanding with the attack on Pearl Harbor in 1941 to the Pacific War, the Fifteen Years War resulted in bitter and desperate conditions experienced by Japanese people. Under these circumstances, the military sponsored with determination the production war paintings, a form of propaganda accomplished in monumental dimensions. The authorities believed that powerful works with accurate depictions would not only inform future generations of patriotic spirits, but also educate the public about the bravery of the troops in order to increase devotion to the war effort [7]. Living in a society engaged in total war, Fujita was incited to become Japan's leading painter of war propaganda. The glorious ideology of liberation associated with the war inspired the artist to work with passion. In his own exhortatory words, "when the nation is at war, I would like as many artists as possible to paint war-related works, even if they do so all by themselves. These works will be a force in stirring up the people's belief in our inevitable victory and will be a great mission to leave to future generations" [1]. Cutting his long hair into a militaristic crew cut, he began again to use mass media to cultivate his new identity as a patriotic painter who fought a battle with his brush, together with the soldiers at the front. 
As Fujita's white canvas gradually disappeared, he abandoned his previous style of painting female nudes and grew increasingly interested in public art. The war provided dramatic military spectacles to paint. The first major war painting that Fujita produced was Battle on the Bank of the Haluha (1941). The painting was based on the theme of the Battle of Nomonhan, the military clash between Japanese and Soviet forces in July 1939 [6]. It portrays a winning moment of Japanese soldiers attacking Soviet tanks. Three soldiers on the right side of the panel have reached the top of the tank and stick their bayonets inside. Elsewhere on the ground, a group of Japanese soldiers crawl forward through the grass, advancing to seize another burning Soviet tank. In a wide panoramic view of grassland, Fujita provided an immense and mostly empty battleground, with a field close to the picture plane and a sky dripping down low to the horizon. The field is continuous and open, suggesting an extension of canvas into the real world. With a strong sense of three-dimensionality, the composition allows viewers to enter into the picture as if they are one of the solider crawling forward.

Fujita employed bright pigments in this painting, which was seemingly quite distinct from his later deathly battle paintings. Presenting the Japanese in a moment of triumph in the battle at Nomonhan, Fujita manifested the intrepid war spirit praised by the government and elicited an emotional impact upon viewers. However, he left out the part about how the confrontation ended weeks later with the Japanese defeated and twenty thousand soldiers dead [1]. Therefore, the painting is both memorable and misleading, but none of the critics was incline to point out the omission because Fujita had produced the correct image to convey the government's message to the public.

A painting of significant size like Battle on the Bank of the Haluha served a propaganda value that was amplified by their dissemination in printed reproduction and at exhibitions that traveled around Japan to rouse the public's martial spirit. The largeness of the canvas provokes an effect of enveloping viewers, allowing them to place themselves in the experience of the war and thereby reviving the collective sentiments. In 1941, Fujita was appointed as a member of the Imperial Art Academy, and from 1943 he chaired the Army Art Association, the largest quasi-military art collective [6]. Energized by the challenges and opportunities offered by the war, Fujita painted more war paintings than any other war artists and threw himself into creation of large compositions filled edge to edge by a mass of bodies.

Fujita's best-known war painting, Last Stand at Attu (1943), illustrated the event of the Japanese soldiers fighting to their death while knowing they would lose the battle to the American force on Attu Island of the Aleutian chain on May 29, 1943. "During more than two weeks of fighting in cold and fog, most of the island's Japanese defenders were killed. Urged on by their commander, the remaining Japanese refused to surrender and vowed to fight to the last man" [1]. In this work, Fujita dramatized the event in a pictorial maelstrom of human bo- 
dies. He displayed a more aggressive image than that of Battle on the Bank of the Haluha in a large earthy-toned monochrome canvas. The law of perspective and ordered spatial configuration are disturbed in Fujita's painting. The extreme foreground of the painting is flattened and teemed with interlaced bodies, creating a claustrophobic space of battle. The background, occupying the upper third of the image, is comprised of a violent seascape with dramatic waves rising from the sea and crashing on rocks, just as wave of warriors crashing against the enemy. Due to the lack of a middle-ground and the solid sense of volume with which each soldier's body was depicted, the overall impression is of figures compressed into a two-dimensional space in which bodies of soldier piled up, intermingle, and overlap. The static canvas is enlivened by the dramatic multi-figure composition, and this effect is enhanced by various indications of movements across the canvas.

The attack on Attu was led by the officer Yamazaki Yasuyo, who appears near the upper center of the panel shouting and leading the troop with sword in hand. The Japanese soldiers occupying upper left and middle of the composition are illustrated as brutal and violent, some baring their teeth and penetrating the bodies of American soldiers by wielding their bayonets wildly. Yamazaki is one of the few recognizable figures in the work, the rest of the Japanese and American soldiers are relatively undistinguished, and none are individualized, much like the corpses located in the foreground. The distinction between the Japanese and American troops is difficult and the difference between the enemy dying and Japanese dying remains obscure. Additionally, the painting does not immediately appear uplifting. Besides celebrating the heroic aspects of war, it alludes to the painful confrontation, which generates a complex feeling upon viewers. This scene is not momentary, but an abiding characteristic of war. Fujita seemed to demonstrate an irresistible tragedy rather than praising the heroic act of Japanese defeating enemy. As the leader of the Army Art Association who was supposed to have promoted the war, Fujita created works that had been conceived as "antiwar" due to these reasons. Although the painting had triggered debates about whether it represented warfare appropriately, it was never removed from the exhibition or publication. Rather, according to Maki Kaneko, "Fujita solidified his status as the top-rated official war painter with Attu and a series of deathly battle pictures" [6].

On the contrary, one of Fujita's contemporaries, Miyamato Saburo, constructed a hierarchical relationship between the two military groups. His painting The Meeting of General Yamashita and General Percival (1942) documents the scene of the surrender of Singapore on February 15, 1942. He captured the famous moment when "Lieutenant-General Yamashita Tomoyuki asked Lieutenant-General Arthur Ernest Percival of British Army to accept the settlement's capitulation to Japan by answering, 'yes' or 'no'". He illuminated the victory of his country by adopting the visual language of European academic paintings to depict Japanese soldiers and celebrate Japanese superiority. The influence of art- 
ist Delacroix and Gericault can be found in this painting. Since modern tendencies of abstraction or Surrealism were considered unsuitable for this type of paintings, European paintings in the early nineteenth century assumed great significance of serving as important models for many of the war painters. By exquisitely juxtaposing the well-built physique of Yamashita and the weakness of Percival, both sides become more impressive. Moreover, Miyamato's composition and adjustment of each figure's placement indicate a contrast between the two groups of military officers. As Kaneko observes, Yamashita and the other Japanese officers are shown at the center of the painting, in formal wear and static pose, conversely, the British officers are placed closer to the foreground, leaning forward on the table and showing their backs to the viewers [6]. The dignity of Yamashita is further strengthened when Percival appears in such passive position.

Miyamoto reclaimed the superiority of the Japan by westernizing the Japanese body and inverting the stereotyped perception of the physical difference between Asian and European. Fujita's strategy was different. As an artist who had been carefully cultivating his Japanese identity to purse his career in the European society, he seemed to maintain both his admiration for and confrontational standing against the longstanding Western artistic hegemony. Instead of representing the enemies as inferior to the Japanese, Fujita treated both sides as military bodies resolved to fight with complete disregard for their personal safety. In that sense, he built up the physique and the spirit of the enemies to demonstrate the bravery of the Japanese soldiers in confronting formidable enemies.

\subsection{Shadows of the War}

The war ended following the Japanese emperor conceding defeat on August 15, 1945. Due to his enthusiastic engagement with military during the war, Fujita was heavily criticized for his war-related propaganda art. Japanese art critic Hijikata Teiichi questioned the sincerity of the artist and the true meaning of realism in art. He remained critical of those artists who, during the war years, concerned themselves only with a realistic rendering on the surface of their paintings, yet shied away from seeing the deeper meaning of what the depicted [8].

In the same year, the Metropolitan Museum of Art decided to collect Japanese war art for a triumphal exhibition about the conquest of Japan. Among a collection of 153 war paintings delivered to the Americans, many works were created by Fujita. Departing from assertion of Japanese superiority, paintings made by him in the years of war seemed to have the underlying intentions of reaching a wider audience. He portrayed an equal relationship between Japan and Euro-American nations. Unlike most Japanese war paintings, which were intended to guide the viewers to an unmistakable recognition of the expected role of each nation, the ambiguity engendered in Fujita's painting in distinguishing the Japanese from American soldiers allowed it to be praised by both parties for the brave attitude of the soldiers. His war paintings differ significantly from other 
propaganda paintings because they are historical records of the suffering endured by people. Much like his creation of an original canvas in the 1920s, Fujita's war paintings can be considered as his endeavor to convey the true nature of war and to take control of his own image, which was at odds with militarist ideology.

\section{Conclusion}

Fujita's fame as a painter of European nudes in Paris in the 1920s would seem to be an unlikely prelude for the emergence of the most prominent and prolific artists in the early 1940s of combat scenes of Japanese soldiers. The changes of his handling of image are also remarkable, from the near-monochromatic white surface to the earthy brown panoramas. His canvas, which had been dedicated to the depiction of a nude female figure, turned into a large composition teemed with a mass of interlaced bodies of dying and dead soldiers. Nevertheless, in both France and Japan, Fujita had resisted convention both artistically and socially. Rather than being derivative of Western modern art, he had created a personal artistic language in Paris during the 1920s that transmitted the European female bodies in a medium associated with Japanese cultural identity. Fujita overcame the Western quality of his medium and consolidated his personal authorship of images. Likewise, he subverted Japan's wartime ideology through vividly delineating violence in his war paintings, which captured the suffering of soldiers and described the brutal reality of the war. Fujita, in both his life and art, resists to blindly follow the trend. Through his artworks, Fujita was making a strong statement about his own existence in the modern world. His simple motto, "don't imitate others", had a lasting influence on Japanese artists who were later involved in the production of postwar art scene [9].

\section{References}

[1] Birnbaum, P. (2006) Glory in a Line: a Life of Foujita: The Artist Caught between East and West. Faber, New York, 20-253.

[2] Girard, X. (2013) Paris in the 1920s: With Kiki de Montparnasse. Assouline, New York, 98-102.

[3] Buruma, I. (2014) Theater of Cruelty: Art, Film, and the Shadows of War. New York Review Books, 294-298.

[4] Cannon, J. (2015) The Paris Zone: A Cultural History, 1840-1944. Farnham, Surrey, Ashgate, England, 120.

[5] Winther-Tamaki, B. (2014) Maximum Embodiment Yoga, the Western Painting of Japan, 1912-1955. University of Hawaii Press, 82.

[6] Kaneko, M. (2015) Mirroring the Japanese Empire: The Male Figure in Yoga Painting, 1930-1950. Brill, Leiden, 24-49.

[7] Mayo, M.J., et al. (2001) War Occupation and Creativity: Japan and East Asia 1920-1960. University of Hawaii Press, 188.

[8] Sandler, M.H. (1997) The Confusion Era: Art and Culture of Japan during the Allied Occupation, 1945-52. Arthur M. Sackler Gallery, Washington DC, 24.

[9] Stewart, J. (2010) Flotsam. Paul Dry Books, 14. 